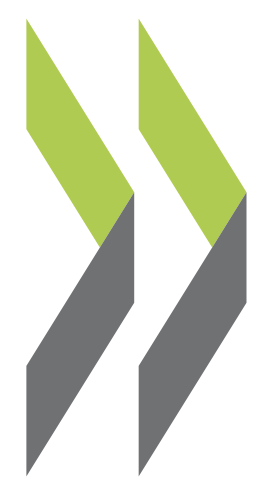

OECD Economics Department Working Papers No. 916

Systemically Important

Banks and Capital

Patrick Slovik

Regulation Challenges 
Organisation de Coopération et de Développement Économiques

Organisation for Economic Co-operation and Development

11-Dec-2012

ECONOMICS DEPARTMENT

English - Or. English

\section{SYSTEMICALLY IMPORTANT BANKS AND CAPITAL REGULATIONS CHALLENGES}

ECONOMICS DEPARTMENT WORKING PAPER No. 916

By Patrick Slovik

All Economics Department Working Papers are available through OECD's internet web site at www.oecd.org/eco/working papers

JT03332575

Complete document available on OLIS in its original format

This document and any map included herein are without prejudice to the status of or sovereignty over any territory, to the delimitation of international frontiers and boundaries and to the name of any territory, city or area. 


\title{
SUMMARY/RÉSUMÉ
}

\author{
Systemically Important Banks and Capital Regulation Challenges
}

Bank regulation might have contributed to or even reinforced adverse systemic shocks that materialised during the financial crisis. Capital regulation based on risk-weighted assets encourages innovation designed to circumvent regulatory requirements and shifts banks' focus away from their core economic functions. Tighter capital requirements based on risk-weighted assets may further contribute to these skewed incentives. The estimated macroeconomic costs of redirecting banks' attention away from such unconventional business practices are low. During a medium-term adjustment period, for each percentage point of bank equity, regulation that is not based on risk-weighted assets would affect annual GDP growth by -0.02 percentage point more than under the risk-weighted assets framework. Refocusing banks' attention toward their main economic functions is a core requirement for durable financial stability and sustainable economic growth.

JEL classification: G01; G21; G28.

Keywords: Basel Accord; Basel III; Financial Regulation; Capital Requirements; Systemically Important Financial Institutions; Too-big-to-fail; Bank Leverage; Financial Crisis; Financial Stability.

$* * * * * * * * * *$

\section{Banques d'importance systémique: défis pour la réglementation du capital}

La réglementation bancaire pourrait avoir contribué, voire renforcé, des chocs systémiques qui se sont matérialisés lors de la crise financière. La réglementation des fonds propres fondée sur des actifs pondérés par les risques encourage l'innovation conçue pour contourner les exigences réglementaires et éloigne les préoccupations des banques de leurs principales fonctions économiques. Le resserrement des exigences en capital fondées sur les actifs pondérés du risque peut exacerber ce biais d'incitation. Des estimations suggèrent que rediriger l'activité des banques hors de telles pratiques commerciales nonconventionnelles ne serait guère coûteux. Pendant une période d'ajustement de moyen terme, pour chaque point de pourcentage du ratio de capitaux propres bancaires, une réglementation qui ne s'appuie pas sur les actifs pondérés du risque réduirait la croissance annuelle du PIB de seulement 0,02 point de pourcentage de plus qu'une réglementation fondée sur les actifs pondérés par les risques. Un recentrage de l'attention des banques vers leurs principales fonctions économiques est une exigence fondamentale pour garantir la stabilité financière et une croissance économique durables.

Classification JEL: G01 ; G21 ; G28.

Mots-clés: Accord de Bâle ; Bâle III ; Réglementation financière ; Réglementation du capital ; Institutions financières d'importance systémique ; Levier bancaire ; Crise financière ; Stabilité financière.

\section{(C) OECD (2012)}

You can copy, download or print OECD content for your own use, and you can include excerpts from OECD publications, databases and multimedia products in your own documents, presentations, blogs, websites and teaching materials, provided that suitable acknowledgment of OECD as source and copyright owner is given. All requests for commercial use and translation rights should be submitted to rights@oecd.org. 


\section{TABLE OF CONTENTS}

Systemically Important Banks and Capital Regulation Challenges............................................... 5

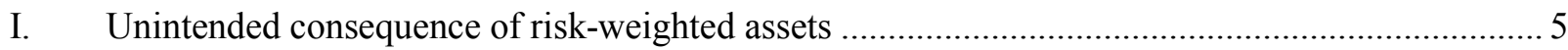

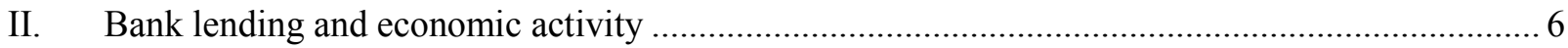

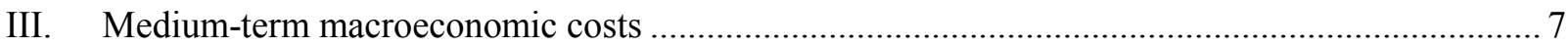

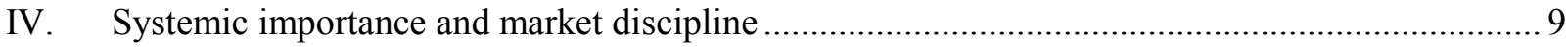

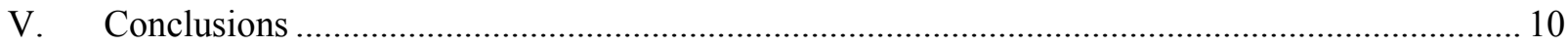

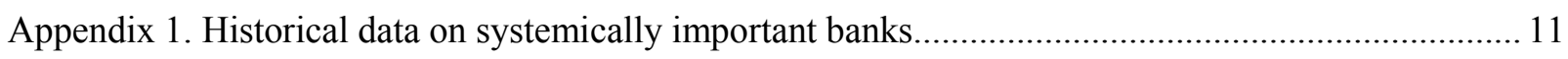

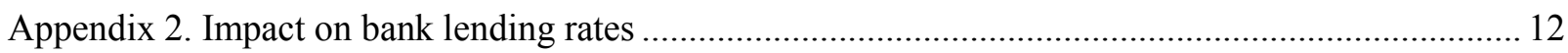

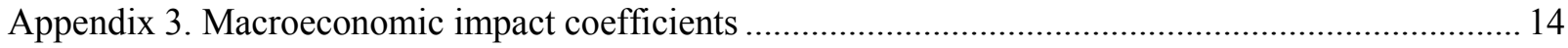

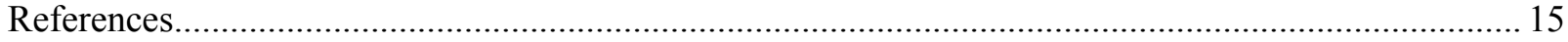

\section{Tables}

1. Total loans to total assets: A historical perspective for selected banks ....................................... 7

2. Effects of higher capital requirements on bank lending spreads .............................................. 7

3. Medium-term impact of higher capital requirements on annual GDP growth ............................... 8

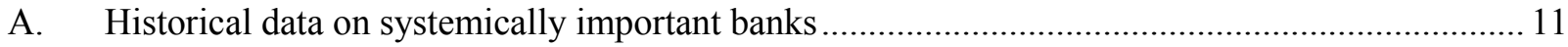

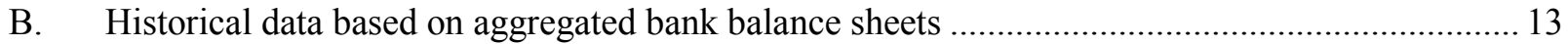

C. Macroeconomic impact of a 100 basis point increase in bank lending rates................................. 14

D. Macroeconomic impact of a one percentage point increase in bank capital ratios......................... 14

\section{Figures}

1. Historical development of the RWA/TA ratio of systemically important banks ........................... 6

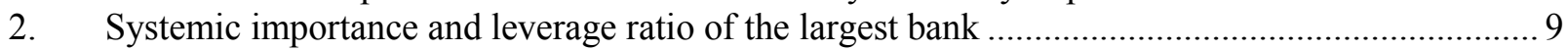


ECO/WKP(2011)85 
ECO/WKP(2011)85

\title{
SYSTEMICALLY IMPORTANT BANKS AND CAPITAL REGULATION CHALLENGES
}

\author{
by
}

Patrick Slovik ${ }^{1}$

1. The simultaneous failure of markets and regulators to discipline systemically important banks before the financial crisis resulted in significantly negative consequences for economic output and government expenditures. This study discusses aspects of the failure of bank regulation and market discipline. Section I provides a perspective on the unintended consequences of bank regulation and argues that capital regulation might have contributed to or even reinforced adverse systemic shocks that materialised during the financial crisis. Section II discusses the conflict between the original role of banks in the economic system, which is to evaluate and provide loans to credit-worthy borrowers, and the decline in the profitability of this activity relative to other sources of bank income. The study finds, in Section III, that the economic costs of redirecting bank attention away from unconventional business practices are low. Section IV examines the relationship between the level of systemic importance of banks and their leverage. Financial market policy considerations and conclusions are drawn in Section V.

\section{Unintended consequence of risk-weighted assets}

2. Systemically important banks have consistently decreased the base for the calculation of their regulatory capital. When the first Basel accord was implemented in 1992, risk-weighted assets represented close to $70 \%$ of bank total assets, which means that bank regulatory capital was calculated based on a large share of bank total exposures. In the years following the introduction of the Basel accord, the ratio of riskweighted assets to total assets (RWA/TA ratio) gradually decreased and reached about $35 \%$ in the immediate pre-crisis period (Figure 1), which means that the regulatory capital of systemically important banks was calculated based on only a small fraction of their total exposures. The significant drop in the risk-weighted assets ratio implies that either (a) the exposures of systemically important banks were in the immediate pre-crisis period only half as risky as during the previous decade or (b) the regulatory framework based on risk-weighted assets omitted a huge proportion of the actual risk exposures of systemically important banks. Given the unprecedented scale of the financial crisis, the latter alternative is far more likely.

1. Patrick Slovik is an economist at the OECD. The author is particularly indebted to Adrian BlundellWignall for providing the inspiration for the analysis reported in this working paper. The author is grateful to Jørgen Elmeskov, Sveinbjörn Blöndal, Boris Cournède, and Stephen Lumpkin for their useful comments, but retains responsibility for any remaining errors. The opinions expressed in this paper are those of the author and do not necessarily reflect the views of the OECD or its member countries. 
Figure 1. Historical development of the RWA/TA ratio of systemically important banks

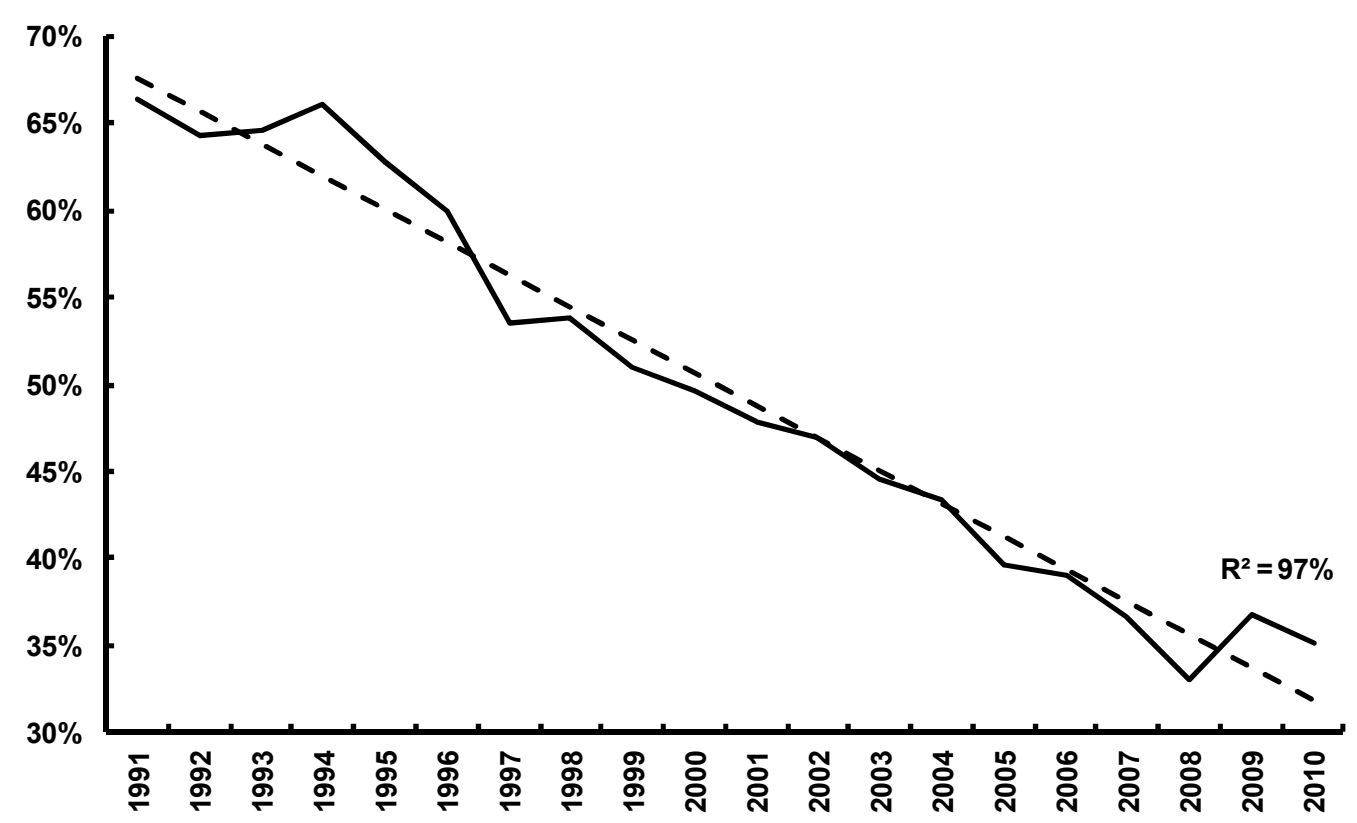

Source: The Banker Database, Author's calculations and estimates, See Appendix 1. For a similar chart for selected individual banks, see Figure 14 in Blundell-Wignall and Atkinson (June 2011).

3. As Figure 1 demonstrates, the drop in the RWA/TA ratio has been very smooth since the implementation of the Basel accords without any significant deviations from the trend line until the crisis. This trend suggests that innovative engineering of regulatory risks and the move to unconventional business practices by systemically important banks has been a consistent trend for almost two decades and was not limited to a few years preceding the financial crisis. The trend reached its lowest point at the onset of the financial crisis when the capital requirements of systemically important banks were determined based on the historically lowest amounts of risk-weighted assets (relative to total assets). Risk-weighted regulation leads to unintended consequences as it encourages innovation designed to bypass the regulatory regime rather than to serve non-financial enterprises and households. Strengthening capital requirements based on risk-weighted assets may further contribute to these skewed incentives and their profitability. Appendix 1 provides more information on the construction of Figure 1 and additional statistics on systemically important banks.

\section{Bank lending and economic activity}

4. A core function of banks is to actively search for and evaluate lending opportunities and advance loans to credit-worthy enterprises and households. In the past, such activities accounted for the major share of large banks' assets. However, this share has declined substantially over time. Table 1 depicts the historical development of the ratio of total loans to total assets for selected large banks in the United States, the United Kingdom, Germany, France, and Switzerland. As the table shows, the loan portfolio represented around $75 \%$ of total assets of these banks in the early 1990s. Thereafter, the ratio of loans to total assets gradually declined to a low of around $30 \%$ in the immediate pre-crisis period. One of the main reasons why non-loan-related activities have become so important for banks is the relatively high regulatory riskweights on loans relative to other types of assets, which puts them at a comparative disadvantage in the profit-seeking strategies of banks. In effect, capital regulation based on risk-weights creates incentives for banks to focus on non-lending activities. 
Table 1. Total loans to total assets: A historical perspective for selected banks (percentages)

\begin{tabular}{|c|c|c|c|c|c|c|c|c|}
\hline & 1990 & 1995 & 2000 & 2005 & 2007 & 2008 & 2009 & 2010 \\
\hline Deutsche Bank & 85 & 73 & 53 & 17 & 11 & 15 & 21 & 27 \\
\hline UBS & 78 & 61 & 26 & 15 & 18 & 21 & 27 & 22 \\
\hline BNP Paribas & 77 & 73 & 37 & 28 & 31 & 28 & 36 & 38 \\
\hline Barclays & 78 & 68 & 64 & 33 & 32 & 25 & 34 & 32 \\
\hline Bank of America & 58 & 62 & 61 & 44 & 51 & 51 & 40 & 42 \\
\hline
\end{tabular}

Source: Thomson Reuters Datastream, Author's calculations and estimates.

5. Even during the boom in mortgage lending, prior to the financial crisis, banks at the centre of the crisis lacked strong incentives to devote adequate attention to due diligence of individual mortgage loans because their main profit margins were derived from securitisation of loans rather than from a prudent credit-risk assessment of individual loans. A major focus of systemically important banks has been to maximise profits by engineering unconventional assets, rather than making sure that each loan individually is worth the credit risk. Risk-weighted regulation shifts banks' attention and resources away from conventional lending. In contrast, regulation based on non-risk-weighted total assets places the same emphasis on loans as on other bank assets. In a framework where all assets bear the same regulatory cost, non-lending activities with the sole aim of exploiting or circumventing risk-weights would become unprofitable.

\section{Medium-term macroeconomic costs}

6. A commonly held view against regulation based on non-risk-weighted total assets (such as a leverage ratio) is that it would negatively affect the overall economy as banks would pass along a rise in their funding cost to their customers by increasing lending spreads. Table 2 compares the impact on bank lending spreads of a one percentage point increase in the ratio of equity to risk-weighted assets versus a one percentage point increase in the ratio of equity to total assets. For a one percentage point increase in equity requirements, a non-risk-weighted regulatory framework is estimated to increase lending spreads on average by 7.2 basis points ( 0.072 percentage point) more than in the case of risk-weighted regulation. This difference in the impact on bank lending spreads is estimated based on accounting identities applied to aggregated bank balance sheets. The reader can find a detailed description of the estimation method in Appendix 2.

Table 2. Effects of higher capital requirements on bank lending spreads (basis points)

Impact of a 1 percentage point increase in equity to total assets vs. equity to risk-weighted assets

\begin{tabular}{|c|c|c|c|}
\hline & $\begin{array}{c}\Delta \text { Bank Lending Spreads } \\
\text { (Equity to Total Assets) }\end{array}$ & $\begin{array}{c}\Delta \text { Bank Lending Spreads } \\
\text { (Equity to Risk-Weighted Assets) }\end{array}$ & Difference \\
\hline United States & 26.8 & 20.5 & 6.3 \\
\hline Euro area & 26.5 & 14.3 & 12.2 \\
\hline Japan & 11.6 & 8.4 & 3.2 \\
\hline Average (unweighted) & 21.6 & 14.4 & 7.2 \\
\hline Average (GDP w eighted) & 24.3 & 16.1 & 8.2 \\
\hline
\end{tabular}

Source: Author's calculations and estimates. 
7. The medium-term macroeconomic impact is illustrated in Table 3, which shows the differences in the impact on annual GDP growth of an increase in the ratio of bank equity to risk-weighted assets and equity to total assets. For a one percentage point increase in the equity ratio, a non-risk-weighted regulatory framework would reduce medium-term annual GDP growth on average by only 0.02 percentage point more than risk-weighted regulation. ${ }^{2}$ This impact on economic activity is estimated based on changes in bank lending rates shown in Table 2 above and the macro-economic impact coefficients during a fiveyear adjustment period estimated by Slovik and Cournède (2011). ${ }^{3}$ The estimated effect is larger, though still small, in the euro area mainly due to (i) a greater share of bank credit intermediation in total credit intermediation in the euro area economy and (ii) a larger impact on bank lending spreads resulting from differences in accounting standards. ${ }^{4}$

Table 3. Medium-term impact of higher capital requirements on annual GDP growth (percentage points)

Impact of a 1 percentage point increase in equity to total assets vs. equity to risk-weighted assets

\begin{tabular}{lcccc}
\hline & $\begin{array}{c}\Delta \text { GDP Growth } \\
\text { (Equity to Total Assets) }\end{array}$ & & $\begin{array}{c}\Delta \text { GDP Grow th } \\
\text { (Equity to Risk-Weighted Assets) }\end{array}$ \\
\cline { 2 - 3 } United States & -0.05 & -0.04 & -0.01 \\
Euro area & -0.11 & -0.06 & -0.05 \\
Japan & -0.03 & -0.02 & -0.01 \\
Average (unweighted) & -0.06 & -0.04 & -0.02 \\
Average (GDP weighted) & -0.07 & -0.04 & -0.03 \\
\hline
\end{tabular}

Source: Author's calculations and estimates.

8. The estimated differences in Tables 2 and 3 can be considered as conservative and in practice could be even lower. First, a one percentage point increase in the ratio of equity to total assets represents a higher increase in loss-absorption capacity than a one percentage point increase in the ratio of equity to risk-weighted assets; a higher loss-absorption capacity in turn implies a safer banking system, which would reduce bank borrowing costs and thus imply a smaller increase in bank lending rates. Second, the differences in the estimated impact reflect the assumption of no active response from monetary policy; a larger impact on bank lending spreads would in practice lead to a stronger monetary policy response and thus cushion the impact on economic activity. Third, if unconventional bank activities were to become less profitable, banks would presumably redirect their resources (including high-quality human capital) to conventional bank activities, implying better credit-risk assessments and more efficient financial intermediation.

2. The medium-term macroeconomic impact shown in Table 3 represents an average impact on annual growth during a five-year adjustment period; beyond the medium term, annual GDP growth will revert to trend.

3. For more details on the macroeconomic impact coefficients see Appendix 3.

4. The IFRS accounting standard used in the euro area disallows netting of derivatives, which leads to a higher measure of total assets and thereby a larger macroeconomic impact compared to the GAAP accounting standard used in the United States. Looking further ahead, a convergence of standards across jurisdictions will lead to a convergence of the macroeconomic impact measures. 


\section{Systemic importance and market discipline}

9. Market forces should, in principle, correct for regulatory imperfections and prevent banks from taking excessive risks. However, the greater the systemic importance of a bank, the higher is the chance that it will be rescued by either the central bank or the government to prevent negative system-wide consequences. In view of such implicit guarantees, markets often fail to discipline large banks to hold prudent capital levels and make sound investment decisions. To illustrate this point, Figure 3 compares the systemic importance of a bank in its home jurisdiction with its leverage. Systemic importance of a bank (x axis) is defined as total assets of the largest bank in the country to gross domestic product (GDP). The leverage ratio (y axis) is calculated as total assets of the bank to its Tier 1 capital. The data in Figure 3 reveal that across OECD countries the bank leverage ratio is strongly correlated with the measure of bank systemic importance. The only notable outlier, on the high end of the 33 observations, is Germany with the leverage ratio of its largest bank the highest in the sample.

Figure 2. Systemic importance and leverage ratio of the largest bank (end-2009)

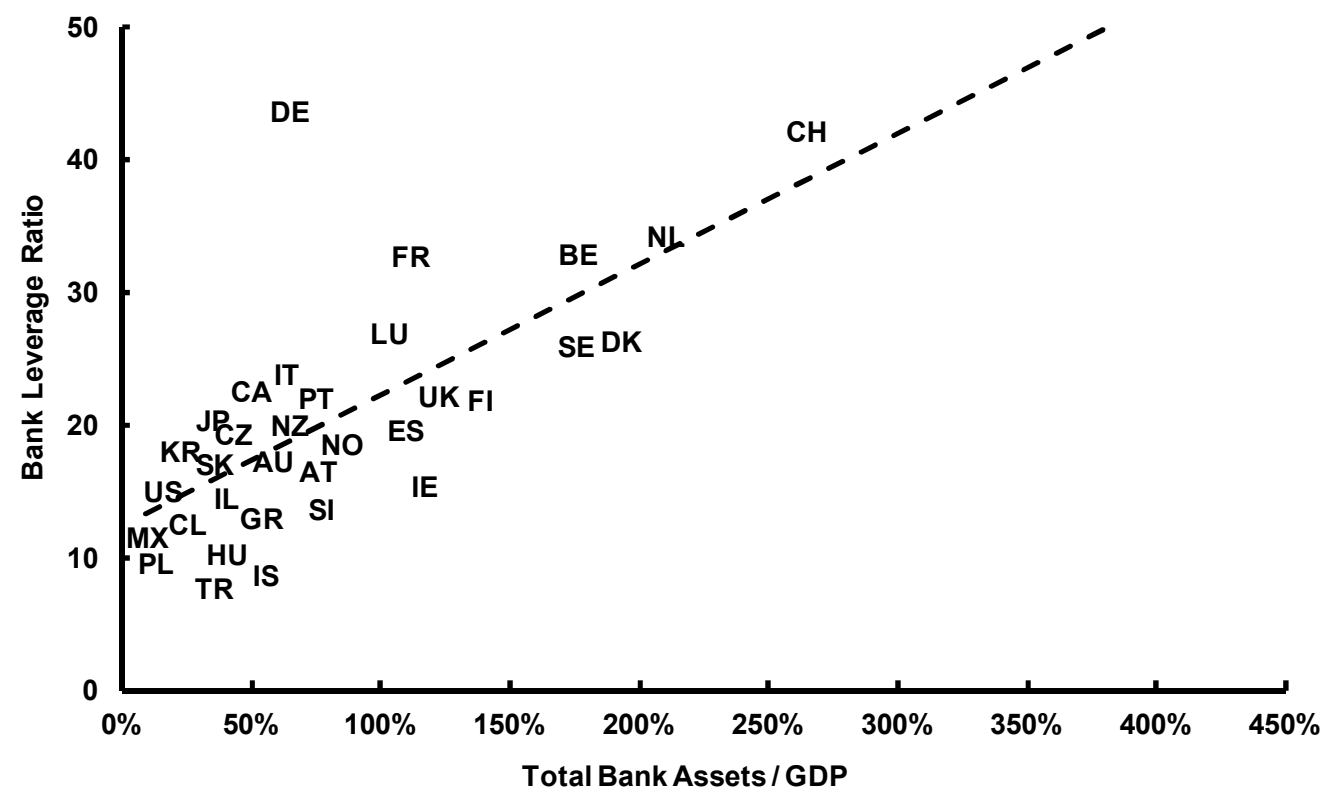

Note: $\quad$ The correlation between the 32 observations (excl. Germany) and a linear trend line is $71 \%$. Including the observation for Germany, the correlation between the 33 observations for all OECD countries and a linear trend line amounts to $53 \%$.

Source: $\quad$ The Banker Database, Author's calculations and estimates.

10. The failure of markets to discipline systemically important banks has amplified existing regulatory imperfections. In contrast, in the run up to the crisis, the majority of small and medium-sized banks did not take on excessive leverage or engage in unconventional business practices, because their shareholders and creditors did not permit it. Bank regulation is not sufficient on its own and the lack of market discipline creates scope for financial instability. Without sufficient market discipline, capital surcharges for systemically important banks based on risk-weighted assets might only create stronger incentives to circumvent regulatory costs. Therefore, it could be more suitable to base additional capital requirements for systemically important banks on a non-risk-weighted framework. 


\section{$\mathrm{ECO} / \mathrm{WKP}(2011) 85$}

\section{Conclusions}

11. The anticipated benefits of a new regulatory regime often tend to be significantly overstated ${ }^{5}$ because they are net of any unintended consequences, which are naturally not reflected in historical experience and time-series and therefore impossible to estimate. When the Basel accord first introduced the calculation of regulatory capital requirements based on risk-weighted assets, it was not expected that for systemically important banks the share of risk-weighted assets in total assets would consequently drop from $70 \%$ to $35 \%$. Nor was it expected at the time that the financial system would transform high-risk subprime loans into seemingly low-risk securities on a scale that would spark a global financial crisis. Given the enormous scale of the experienced adverse systemic shock, rational policymakers should be cautious in estimating benefits of a new regulatory regime based on either econometric models or expert judgment. Tighter capital requirements based on risk-weighted assets aim to increase the loss-absorption capacity of the banking system, but also increase the incentives of banks to bypass the regulatory framework. New liquidity regulation, notwithstanding its good intentions, is another likely candidate to increase bank incentives to exploit regulation.

12. Bank regulation cannot impose financial stability unilaterally without the market playing an active role in enforcing bank discipline. The main source of the failure of markets to discipline systemically important banks is that investors and creditors consider the risks of their losses implicitly guaranteed in the current state of affairs. Increasing the capacity of markets to discipline banks will require addressing the too-big-to-fail problem, strengthening and rationalising bank resolution regimes, and improving bank information disclosures. The Basel accords provide an internationally comparable and standardised set of rudimentary best practices in bank regulation, but they can only perform well in synergy with the market. The introduction of a leverage ratio based on non-risk-weighted total assets would help to align banks' activities with their main economic functions and maximise capital-allocation efficiency. Although a common argument against a stringent leverage ratio is that it would increase bank lending cost and negatively affect the economy, this study has shown that the differences between the macroeconomic impact of risk-weighted and non-risk-weighted regulatory regimes are relatively low.

5. See also Suttle (2011). 


\section{APPENDIX 1. HISTORICAL DATA ON SYSTEMICALLY IMPORTANT BANKS}

The statistics referenced in Section I of this study are calculated as a weighted average for 15 of the largest systemically important banks ${ }^{6}$ in the United States, the euro area, the United Kingdom, and Switzerland. This set of banks comprises UBS, Barclays, BNP Paribas, Citigroup, HSBC, Credit Agricole, Royal Bank of Scotland, Deutsche Bank, Bank of America, ABN AMRO, Societe Generale, ING Bank, Banco Santander, UniCredit, and Credit Suisse. Table A depicts the main historical data for this group of banks: (a) the ratio of risk-weighted assets to total assets (RWA/TA), (b) the leverage ratio calculated as total assets to Tier 1 capital, and (c) the Tier 1 ratio calculated as Tier 1 capital to risk-weighted assets.

Table A. Historical data on systemically important banks

\begin{tabular}{ccccc}
\hline & RWA/TA & Leverage Ratio & Tier 1 Ratio \\
\cline { 2 - 3 } 1991 & $66 \%$ & 23 & $7 \%$ \\
1992 & $64 \%$ & 24 & $6 \%$ \\
1993 & $65 \%$ & 22 & $7 \%$ \\
1994 & $66 \%$ & 21 & $7 \%$ \\
1995 & $63 \%$ & 21 & $7 \%$ \\
1996 & $60 \%$ & 23 & $7 \%$ \\
1997 & $53 \%$ & 24 & $8 \%$ \\
1998 & $54 \%$ & 23 & $8 \%$ \\
1999 & $51 \%$ & 24 & $8 \%$ \\
2000 & $50 \%$ & 25 & $8 \%$ \\
2001 & $48 \%$ & 25 & $8 \%$ \\
2002 & $47 \%$ & 25 & $9 \%$ \\
2003 & $44 \%$ & 26 & $9 \%$ \\
2004 & $43 \%$ & 28 & $8 \%$ \\
2005 & $40 \%$ & 30 & $8 \%$ \\
2006 & $39 \%$ & 31 & $8 \%$ \\
2007 & $37 \%$ & 35 & $9 \%$ \\
2008 & $33 \%$ & 33 & $11 \%$ \\
2009 & $37 \%$ & 24 & $12 \%$ \\
2010 & $35 \%$ & 24 & \\
\hline
\end{tabular}

Source: The Banker Database, Author's calculations and estimates.

6. The sample of the banks is determined based on their size in 2006, which is the year immediately preceding the financial crisis. 


\title{
APPENDIX 2. IMPACT ON BANK LENDING RATES
}

The impact of Basel III on bank lending spreads in Section III is estimated based on accounting identities applied to aggregated banking sector balance sheets. For the purpose of the estimation, two categories of bank assets are considered: (i) Bank lending assets (AL) that comprise bank credit to households and non-financial corporations held on banking books, and (ii) Other bank assets (AO), which represent a residual category that comprises assets held on trading books, interbank assets, government bonds and other remaining assets. It is assumed that a bank can directly affect the pricing of AL by adjusting its lending spread. The pricing of AO is mainly market driven and it is therefore assumed that a bank cannot directly affect the pricing of these assets. The balance-sheet identity presented in Equation (1) postulates that the return on bank assets is equal to bank funding costs, which are determined by the cost of liabilities and the cost of equity. Equation (2) incorporates a one percentage point increase in bank capital relative to risk-weighted assets. Equation (3) incorporates a one percentage point increase in bank capital relative to total assets. An increase in bank capital will affect bank liability and equity structures and as a consequence the overall bank funding cost. To compensate for the change in funding cost, banks are assumed to adjust their lending spreads, while their costs of equity and debt financing are assumed to remain constant. Combining equations (1) and (2) leads to Equation (4), which shows the increase in bank lending spreads as a result of a one percentage point increase in the ratio of bank capital to risk-weighted assets. Combining equations (1) and (3) leads to Equation (5), which shows the increase in bank lending spreads as a result of a one percentage point increase in the ratio of bank capital to total assets. The data utilised in these estimations that feed into the medium-term macroeconomic impact assessment in Section III, represent an average of the last three pre-crisis years (2004-2006) calculated based on aggregated bank balance sheets and are shown in Table B.

$$
\begin{aligned}
& r_{t}^{A L} \times A L+r_{t}^{A O} \times A O=r_{t}^{L} \times L+r_{t}^{E} \times E \\
& r_{t+1}^{A L} \times A L+r_{t}^{A O} \times A O=r_{t}^{L} \times\left(L-\frac{R W A}{100}\right)+r_{t}^{E} \times\left(E+\frac{R W A}{100}\right) \\
& r_{t+1}^{A L} \times A L+r_{t}^{A O} \times A O=r_{t}^{L} \times\left(L-\frac{1}{100}\right)+r_{t}^{E} \times\left(E+\frac{1}{100}\right) \\
& \left(r_{t+1}^{A L}-r_{t}^{A L}\right)=\frac{\left(r_{t}^{E}-r_{t}^{L}\right)}{A L} \times \frac{R W A}{100} \\
& \left(r_{t+1}^{A L}-r_{t}^{A L}\right)=\frac{\left(r_{t}^{E}-r_{t}^{L}\right)}{A L} \times \frac{1}{100}
\end{aligned}
$$

Legend:

AL - Lending Assets to Total Assets (\%)

AO - Other Assets to Total Assets (\%)

L - Liabilities to Total Assets (\%)

E - Equity to Total Assets (\%)

RWA - Risk-weighted Assets to Total Assets (\%)

\author{
$\mathrm{r}_{\mathrm{t}}^{\mathrm{AL}}$ - Return on Lending Assets (\%) \\ $\mathrm{r}_{\mathrm{t}}^{\mathrm{AO}}$ - Return on Other Assets (\%) \\ $\mathrm{r}_{\mathrm{t}}^{\mathrm{L}}$ - Cost of Borrowing (\%) \\ $\mathrm{r}_{\mathrm{t}}^{\mathrm{E}}$ - Cost of Equity (\%)
}


ECO/WKP(2011)85

Table B. Historical data based on aggregated bank balance sheets (percentages)

\begin{tabular}{|c|c|c|c|}
\hline & $r_{t}^{E}=r_{t}^{L}$ & AL & RWA \\
\hline United States & 12.7 & 47.5 & 76.4 \\
\hline Euro area & 9.4 & 35.4 & 53.9 \\
\hline Japan & 7.7 & 66.0 & 72.0 \\
\hline
\end{tabular}

Note: The data represent an average of the last three pre-crisis years (2004-2006) calculated based on aggregated bank balance sheets.

Source: IIF (2010), Slovik and Cournède (2011), Author's calculations and estimates. 
APPENDIX 3. MACROECONOMIC IMPACT COEFFICIENTS

The macroeconomic impact coefficients utilised in Section III are based on an earlier study by the author $^{7}$ and are summarised in Table C and Table D.

Table C. Macroeconomic impact of a 100 basis point increase in bank lending rates

\begin{tabular}{|c|c|c|c|c|c|c|}
\hline & \multicolumn{5}{|c|}{$\begin{array}{c}\text { GDP level } \\
\text { (percentages) }\end{array}$} & \multirow{2}{*}{$\begin{array}{c}\text { GDP growth } \\
\text { (percentage points) } \\
\text { annual }\end{array}$} \\
\hline & Year 1 & Year 2 & Year 3 & Year 4 & Year 5 & \\
\hline United States & -0.08 & -0.31 & -0.54 & -0.77 & -0.93 & -0.18 \\
\hline Euro area & 0.00 & -0.23 & -0.93 & -1.40 & -2.10 & -0.42 \\
\hline Japan & 0.00 & -0.33 & -0.50 & -1.17 & -1.33 & -0.27 \\
\hline Average (simple) & -0.03 & -0.29 & -0.66 & -1.11 & -1.45 & -0.29 \\
\hline Average (GDP weighted) & -0.03 & -0.28 & -0.69 & -1.08 & -1.45 & -0.29 \\
\hline
\end{tabular}

Source: $\quad$ Slovik and Cournède (2011).

Table D. Macroeconomic impact of a one percentage point increase in bank capital ratios

\begin{tabular}{|c|c|c|c|c|c|c|}
\hline & \multicolumn{5}{|c|}{$\begin{array}{c}\text { GDP level } \\
\text { (percentages) }\end{array}$} & \multirow{2}{*}{$\begin{array}{c}\text { GDP growth } \\
\text { (percentage points) } \\
\text { annual }\end{array}$} \\
\hline & Year 1 & Year 2 & Year 3 & Year 4 & Year 5 & \\
\hline United States & -0.02 & -0.06 & -0.11 & -0.16 & -0.19 & -0.04 \\
\hline Euro area & 0.00 & -0.03 & -0.13 & -0.20 & -0.30 & -0.06 \\
\hline Japan & 0.00 & -0.03 & -0.04 & -0.10 & -0.11 & -0.02 \\
\hline Average (simple) & -0.01 & -0.04 & -0.10 & -0.15 & -0.20 & -0.04 \\
\hline Average (GDP weighted) & -0.01 & -0.05 & -0.11 & -0.17 & -0.22 & -0.04 \\
\hline
\end{tabular}

Source: $\quad$ Slovik and Cournède (2011).

7. Slovik and Cournède (2011). 
ECO/WKP(2011)85

\section{REFERENCES}

Bank for International Settlements (2010), “Assessing the macroeconomic impact of the transition to stronger capital and liquidity requirements", Basel.

Blundell-Wignall, A. and P. Atkinson (2011), "Global SIFIs, Derivatives and Financial Stability", OECD Journal: Financial Market Trends, Vol. 2011/1, Paris.

Blundell-Wignall, A., G. Wehinger, and P. Slovik (2010), "The elephant in the room: The need to deal with what banks do", OECD Journal: Financial Market Trends, Vol. 2009/2, Paris.

Hervé,K. et al. (2010), “The OECD’s New Global Model”, OECD Economics Department Working Paper No. 768., Paris.

Institute of International Finance (2010), "Interim Report on the Cumulative Impact on the Global Economy of Proposed Changes in the Banking Regulatory Framework", Washington, DC.

Slovik, P. and B. Cournède (2011), "Macroeconomic Impact of Basel III", OECD Economics Department Working Papers, No. 844., Paris.

Slovik, P. (2010), "Market Instability and Market Uncertainty", IFC Bulletin No. 34, Proceedings of the IFC Conference, Basel.

Suttle, P. (2011), “The Macroeconomic Implications of Basel III”, IIF Spring Membership Meeting, New Delhi. 
ECO/WKP(2011)85

\section{WORKING PAPERS}

The full series of Economics Department Working Papers can be consulted at www.oecd.org/eco/workingpapers/

915. Improving educational outcomes in Slovenia

(December 2011) by Mehmet Eris

914. Addressing challenges in the energy sector in Israel

(December 2011) by Philip Hemmings

913. Issues in private sector finance in Israel

(December 2011) by Philip Hemmings

912. How to improve the economic policy framework for the housing market in Israel

(December 2011) by Philip Hemmings

911. Fiscal Prospects and Reforms in India

(December 2011) by Richard Herd, Sam Hill and Vincent Koen

910. Structural reforms to reduce unemployment and restore competitiveness in Ireland

(December 2011) by Álvaro Pina

909. Getting back on track: restoring fiscal sustainability in Ireland

(December 2011) by David Haugh

908. A welfare analysis of climate change mitigation policies

(November 2011) by Alain de Serres and Fabrice Murtin

907. Overcoming the banking crisis in Ireland

(November 2011) by Muge Adalet McGowan

906. Macroeconomic and structural policies to further stabilise the Mexican economy

(November 2011) by Cyrille Schwellnus

905. Reaping the benefits of a transition to greener growth in Slovakia

(November 2011) by Caroline Klein

904. Fiscal reform for a stronger fairer and cleaner Mexican economy

(October 2011) by Nicola Brandt and Rodrigo Paillacar

903. The demand for safe assets in emerging economies and global unbalances: new empirical evidence (October 2011) by Rudiger Ahrend and Cyrille Schwellnus

902. Drivers of systemic banking crises: the role of bank-balance-sheet contagion and financial account structure

(October 2011) by Rudiger Ahrend and Antoine Goujard

901. Explaining the appreciation of the Brazilian Real

(October 2011) by Annabelle Mourougane 
900. Raising investment in Brazil

(October 2011) by Jens Arnold

899 Refining macroeconomic policies to sustain growth in Brazil

(October 2011) by Annabelle Mourougane

898. Promoting infrastructure development in Brazil

(October 2011) by Annabelle Mourougane and Mauro Pisu

897. Austria: public sector inefficiencies have become less affordable

(October 2011) by Karin Fischer, Rauf Gönenç and Robert Price

896. Informality in Mexico

(September 2011) by Nicola Brandt

895. Reforming Austria's highly regarded but costly health system

(September 2011) by Rauf Gönenç, Maria. M. Hofmarcher, Andreas Wörgötter

894 Greener growth in the Belgian federation

(September 2011) by Tomasz Koźluk

893. Green growth and climate change policies in New Zealand

(September 2011) by Alexandra Bibbee

892. Has deregulation increased investment in infrastructure? Firm-level evidence from OECD countries

(September 2011) by Sónia Araújo

891. Ensuring a Sustainable and Efficient Fishery in Iceland

(September 2011) by Gunnar Haraldsson and David Carey

890. Japan's New Growth Strategy to create demand and Jobs

(September 2011) by Randall S. Jones and Byungseo Yoo

889. Labour market reforms in Japan to improve growth and equity

(September 2011) by Randall S. Jones and Satoshi Urasawa

888. Education reform in Japan

(September 2011) by Randall S. Jones

887. The Political Economy of Climate Change Mitigation Policies: How to Build a Constituency to Address Global Warming?

(August 2011) by Alain de Serres, John Llewellyn and Preston Llewellyn

886. Climate-Change Policy in the United Kingdom

(August 2011) by Alex Bowen and James Rydge

885. Improving Access and Quality in the Indian Education System

(August 2011) by Sam Hill and Thomas Chalaux 